\title{
IAMJ
}

INTERNATIONAL

AYURVEDIC

MEDICAL JOURNAL

ISSN: 2320-5091

Impact Factor: 6.719

\section{PHARMACEUTICAL AND ANALYTICAL STUDY OF RASANJAN W.S.R AYURVED PRAKASH SAMHITA}

\author{
Gangaprasad Asore', Sachin S Sheth ${ }^{2}$, Kanchan Bhawarlal Suthar ${ }^{3}$ \\ HOD \& Associate Professor, Dept of Rasashashtra \& Bhaishajya Kalpana; \\ Assistant professor, Dept of Rasashashtra \& Bhaishajya Kalpana; \\ P.G Scholar, Dept of Rasashashtra \& Bhaishajya Kalpana, \\ APM's Ayurved Mahavidyalaya, Sion, Mumbai-22, Maharashtra, India
}

Corresponding Author: kanchansuthar2202@gmail.com

\section{https://doi.org/10.46607/iamj1208122020}

(Published online: December 2020)

Open Access

(C) International Ayurvedic Medical Journal, India 2020

Article Received: 28/11/2020 - Peer Reviewed: 29/11/2020 - Accepted for Publication: 30/11/2020

(A) Check for updates

\section{ABSTRACT}

In this study, Daruharidra (Berberis Aristata) and Goat milk is main ingredient, and both have been considered as a very significant herb in many eye and skin disease for external application. The bark is used as the main part of Daruharidra that is used in its crude form as powder or decoction. According to reference of Ayurved Prakasha Samhita, the Goat milk is used in preparation of Rasanjan. The present study is an attempt to prepare Rasanjan and evaluate the quality control parameters by doing analytical study.

Keywords: Rasanjan, Rasakriya, Rasaut, B. aristata, Kwath, Ghana.

\section{INTRODUCTION}

The need of standardization of herbal drugs or formulation is important in the present era for quality control and safety evaluation. Daruharidra is one of the most important drugs in Ayurveda. Extract of $D a$ - ruharidra is also known as Rasanjan, Rasaut, Ghana etc. Berberis species are major source of Berberine and other alkoids namely, Berbamine, Palmatine, isotetrandrine etc ${ }^{[1]}$. B. aristata is an erect shrub with 3- 
6m height and sub-acute leaves ${ }^{[1]}$. Daruharidra and Goat milk both are used as a remedy for treating eye disorders, ear disorders, jaundice, diabetes, fever etc. Rasanjan (Berberis Aristata) or Rasaut is the crude concentrated extract prepared from roots and stem bark of Daruharidra (Berberis aristata) ${ }^{[2]}$. (Family: Berberidaceae). In Rasanjan preparation here Goat milk is used. Goat has tremendous result in eye disease. Rasanjan preparation is carried out in two steps [3]: Kwath preparation of Daruharidra. Ghana preparation. Rasanjan is mostly used as external application but it can also use as internally. After preparing appropriately by taking proper precautions, it should analyze for quality control. It shows stability of formulation physically and chemically. In this study, the pharmaceutical preparation and analysis of Rasanjan is done.

Aim: To study, the pharmaceutical preparation and analysis of Rasanjan.

\section{Objectives:}

1. Primary-

- To study, the Analytical study of Rasanjan.

\section{Secondary}

- Collection of Raw material.

- Authentication of Raw material.

- Preparation of Daruharidra Kwath.

- Preparation of Rasanjan.

- Analytical study of Rasanjan.

Materials and Methods:

1. Collection of Daruharidra from local market.

2. Collection of Goat milk from local market.

3. Authentication of Raw material was done from authenticated laboratory.

4. Preparation of Rasanjan according to reference of Ayurved Prakasha.

5. Quality control of Rasanjan.

Procedure:

Reference: Ayurved Prakasha Samhita 2/231

Preparation of Rasanjan was carried out in 2 steps-

Step I - Preparation of Daruharidra Kwath (Decoction).

Step II -Preparation of Rasanjan.

Step I - Preparation of Daruharidra Kwath ${ }^{[4]}$

Table 1: Ingredients for Daruharidra Kwath

\begin{tabular}{|l|l|l|}
\hline Sr. No & Ingredients & Quantity \\
\hline 1. & Daruharidra & $250 \mathrm{gms}$ \\
\hline 2. & Water & $4000 \mathrm{ml}$ \\
\hline
\end{tabular}

1. Daruharidra stem bark free from insects was taken and washed properly for soil removal.

2. It was soaked in 16 parts of water i.e. $4000 \mathrm{ml}$ for a period of 12 hours.

3. Soaked Daruharidra was kept on moderate flame for heating.

4. It was subjected to heating until the contents were reduced to $1 / 8^{\text {th }}$ i.e. $500 \mathrm{ml}$
5. Then it was filtered through cloth to get decoction of Daruharidra.

\section{Observation:}

- The colour of water changes to yellow after soaking.

- After Kwath preparation, its colour changes to dark brown.

Step II- Preparation of Rasanjan ${ }^{[5]}$

Table 2: Ingredients for Rasanjan

\begin{tabular}{|l|l|c|}
\hline Sr. No & Ingredients & Quantity \\
\hline 1. & Daruharidra Kwath & $500 \mathrm{ml}$ \\
\hline 2. & Goat milk & 125 \\
\hline
\end{tabular}


1. Daruharidra Kwath $500 \mathrm{ml}$ was mixed with $1 / 4$ th quantity of Goat milk and subjected to heating on mild flame.

2. Continuous stirring of the contents was done to avoid sticking of content as the liquid turns into thick (syrupy) in consistency.

3. Further heating was carried out by water bath method to avoid charring.

4. After complete evaporation of liquid content, it was further dried in the Sun and preserved in airtight containers.

\section{Observation:}

- The contents get thick and towards end turn semisolid in consistency.
- Colour turns from dark brown to brownish black.

Precautions:

- Kwath preparation should be done on moderate flame.

- While Kwath preparation, do not cover the pan with lid. Pan should remain open from the top ${ }^{[6]}$

- During Ghana preparation heating should be done carefully and continuous stirring to avoid charring for which Water bath method is the best.

Raw Material Analysis:

A. Daruharidra: Collected from the market and subjected to authentication with classical reference to concerned department.

Table 3: Shows analytical result of Daruharidra

\begin{tabular}{|l|l|l|}
\hline Test & Specifications & Result \\
\hline Appearance & Dried hard stem pieces & Dried hard stem pieces \\
\hline Colour & Yellowish Brown & Light Yellowish Brown \\
\hline Odour & Faint & Faint \\
\hline Taste & Bitter & Bitter \\
\hline Foreign Matter & NMT 2\% & Nil \\
\hline Ash & NMT 14\% & $5.80 \%$ \\
\hline Aia & NMT 5\% & $1.21 \%$ \\
\hline Ase & NMT 6\% & $6.52 \%$ \\
\hline Wse & NMT 8 $\%$ & $8.48 \%$ \\
\hline Moisture Content & NMT 5 $\%$ & $3.5 \%$ \\
\hline
\end{tabular}

\section{B. Goat Milk}

Collected from the local market and subjected to authentication with classical reference to concerned department.

Table 4: Shows analytical result of Goat Milk.

\begin{tabular}{|l|l|}
\hline Colour & White \\
\hline Flavor \& Odour & Satisfactory \\
\hline Texture & Liquid \\
\hline Taste & Normal \\
\hline Consistency & Uniform \\
\hline Acidity\% & $0.13 \%$ \\
\hline Fat $\%$ & $3.6 \%$ \\
\hline Snf $\%$ & $9.0 \%$ \\
\hline Lactose $\%$ & $5.24 \%$ \\
\hline Protein\% & $3.06 \%$ \\
\hline
\end{tabular}

\section{Results:}

1. Organoleptic tests:

Table 5: Organoleptic tests

\begin{tabular}{|l|l|}
\hline Test & Result \\
\hline Appearance & Semi-Solid \\
\hline Colour & Yellowish Brown \\
\hline Odour & Milky \\
\hline Taste & Pungent, Bitter, Sweet. \\
\hline
\end{tabular}

2. Physico- chemical tests ${ }^{[7]}$ Following tests were carried out on prepared Rasanjan samples
A. Moisture value
B. Total ash value
C. Acid insoluble ash
D. Acid insoluble ash
E. Water soluble ash
F. Water soluble extractive value 
G. Alcohol soluble extractive value.

A. Moisture Value: Procedure: $5 \mathrm{gm}$ sample is weighed and kept in a porcelain crucible. Hot air oven thermostat is adjusted to $105^{\circ} \mathrm{C}$ and left for certain time to get stabilized at that temperature. Porcelain crucible with sample is kept on oven tray with equidistant from four walls of oven. Sample is dried for one hour. Porcelain crucible is taken out and kept in desiccator to prevent any moisture absorption. After self-cooling porcelain crucible with sample is weighed to calculate the loss of weight on drying. The percentage content of moisture value is calculated in percentage $(\% \mathrm{w} / \mathrm{w})$.

Percentage Value of Moisture content $=($ Weight of sample obtained/Weight of sample taken) X 100

\section{B. Total Ash Value:}

Procedure: 5 gm Sample is weighed and kept in a silicon crucible. This crucible is kept on wire gauze and heated on a gas stove. It starts emitting fumes and heating is continued until fumes subside. Then this crucible is kept in muffle furnace equidistant from four walls and temperature is gradually raised up to $450^{\circ} \mathrm{C}$ for 6 hours. After complete incineration and after self-cooling, crucible is taken out and kept in a desiccator. The weight of ash with silica crucible is noted. Then the total ash is calculated in terms of percentage $(\% \mathrm{w} / \mathrm{w})$.

Percentage value of total ash content $=$

(Weight of ash obtained/Weight of sample taken) X 100

\section{Acid insoluble Ash Value:}

Procedure: Above prepared ash is washed into a 100 $\mathrm{ml}$ beaker using $25 \mathrm{ml}$. of dilute hydrochloric acid. Beaker is boiled for 5 minutes. Contents are filtered through an ash less filter paper; residue is washed twice with hot water. Filter paper is placed in a silica crucible and incinerated by gradually increasing the heat in a muffle furnace at $450 \mathrm{o} \mathrm{C}$ for some hours. After complete incineration and after self-cooling, crucible is taken out and kept in a desiccator. The weight of ash with silica crucible is noted. Then the acid insoluble ash is calculated in terms of percentage $(\% \mathrm{w} / \mathrm{w})$.

Percentage value of acid insoluble ash $=$
(Weight of ash remained in Crucible/Weight of sample taken) $\mathrm{X} 100$

\section{Water soluble Ash Value:}

Procedure: The method up to preparation of ash is same as above, instead of $25 \mathrm{ml} \mathrm{HCl} 25 \mathrm{ml}$ of distilled water must be used. The weight of ash with silica crucible is noted. Then the loss of ash in water is calculated and water-soluble ash value is quantified in terms of percentage $(\% \mathrm{w} / \mathrm{w})$. Percentage value of water-soluble ash $=($ Weight of ash dissolved in water/Weight of sample taken) X 100

\section{E. Alcohol Soluble Extractive Value:}

Procedure: Sample is weighed and transferred to a $100 \mathrm{ml}$ conical flask. $100 \mathrm{ml}$ of the $90 \%$ alcohol is added to it and closed with the cork. Kept aside for 24 hours with shaking frequently. Filtered, $25 \mathrm{ml}$ of the filtrate is collected and transferred to a weighed, thin Porcelain dish. Evaporated to dryness on a water bath and dried completely in an oven at $100 \mathrm{o}$ C. Kept in a desiccator to cool, then percentage $\mathrm{w} / \mathrm{w}$ of extractive with reference to air dried drug is calculated.

Percentage value of alcohol soluble Extractive value = (Weight of dry extract obtained/Weight of sample taken $\{$ air dried $\})$ X 100.

\section{F. Water Soluble Extractive Value:}

Procedure: Sample is weighed and transferred to a $100 \mathrm{ml}$ conical flask. $100 \mathrm{ml}$ of the $50 \%$ chloroform water is added to it and closed with the cork. Flask is kept aside for 24 hours with frequent shaking. Filtered, $25 \mathrm{ml}$ of the filtrate is collected and transferred to a weighed, thin Porcelain dish. Evaporated to dryness on a water bath and dried completely in an oven at $100 \mathrm{o}$ C. Kept in a desiccator to cool, then percentage $\mathrm{w} / \mathrm{w}$ of extractive with reference to air dried drug is calculated.

Percentage value of alcohol soluble Extractive value = (Weight of dry extract obtained/Weight of sample taken $\{$ air dried\}) X 100.

Table 6: Shows Physico-Chemical result.

\begin{tabular}{|l|l|}
\hline Test & Result \\
\hline Loss On Drying & $6.0 \%$ \\
\hline Ash & $7.2 \%$ \\
\hline Aia & $55.1 \%$ \\
\hline
\end{tabular}




\begin{tabular}{|l|l|}
\hline Alcohol Soluble Extractive Value & $15 \%$ \\
\hline Water Soluble Extractive Value & $18.2 \%$ \\
\hline Water Soluble Ash Value & $60.1 \%$ \\
\hline Microbial \& Fungal Contamination & $\begin{array}{l}\text { Free from fungal } \\
\text { and bacteria }\end{array}$ \\
\hline
\end{tabular}

\section{DISCUSSION}

Rasanjan is extract of Daruharidra it has very high efficacy. Preparation of Rasanjan is mentioned in two Ayurvedic texts. Bhava Mishra the author of Bhava Prakasha puts forward the use of cow's milk for preparation of Rasanjan whereas Rasa Madhava the author of Ayurveda Prakash has given use of goat's milk and procedure for both being the same. Properties of goat's milk according to Ayurved Samhitas i.e. Sheet, Kashaya, Katu, Tikta, laghu, ghrahi and Tridoshara. While preparing Kwath, extract of Daruharidra get settle down in Kwath. It appeared to be Dark yellow in colour, which may be due to presence of Berberine and tannins present in Daruharidra. Its odor is milky due to presence of goat milk. During the Kwath preparation boiling temperature was around $80-90^{\circ} \mathrm{C}$. After preparation of Kwath, goat milk was added and continues stirring were done to avoid charring. In Ghana preparation extract of herbs prepared by evaporation of moisture content of Kwath. Rasanjan is Ghana of Daruharidra and can be easily used. Analytical testing was done it observed that Moisture value is $6 \%$, Total ash is $7.2 \%$, AIA is $55.1 \%$, Water soluble ash value is $60.1 \%$, Alcohol soluble extractive value is $15 \%$ and there's no bacterial or fungal growth seen.

\section{CONCLUSION}

The present study shows that Rasanjan was prepared as per Ayurved Prakasha Samhita's reference with due precautions. The sample was analyzed for its physico-chemical component study at an authorized lab. No bacterial or fungal growth seen in sample. It found to be good quality of Rasanjan which can be used as externally as well as internally for various disorders.

\section{REFERENCES}

1. DravyagunaVidyana, Vol II, Prof. P. V. Sharma, ChoukhambhaBharati Academy, Varanasi, Reprint 2005 page no 537.

2. DravyagunaVidyana, Vol II, Prof. P. V. Sharma, ChoukhambhaBharati Academy, Varanasi, Reprint 2005 page no 539.

3. http://www.rasamruta.com/pdf/PHARMACEUTICOA NALYTICAL_STANDARDIZATION_OF_RASANJANAA_HERBAL_EXTRACT.pdf

4. Sharangdhar Samhita, Dr. Shrimati Shailaja Shrivastav, Choukhambha Orientalia, Varanasi, Reprint- 2009, Madhyamkhanda 2/1-2, Page No 135.

5. Madhav U, Prakash A. commentary by Gulrajsharmamishra. Chuakhambha Bharti Academy, Varanasi, 3/231 Page no 316.

6. Sharangdhar Samhita, Dr. Shrimati Shailaja Shrivastav, Choukhambha Orientalia, Varanasi, Reprint- 2009, Madhyamkhanda 2/7, Page No 136.

7. Analytical study: Ayurvedic Pharmacopoeia of India Part II volume II. Central council of India: Delhi; First edition. 2009.

\section{Source of Support: Nil \\ Conflict of Interest: None Declared}

How to cite this URL: Kanchan Bhawarlal Suthar et al: Pharmaceutical And Analytical Study Of Rasanjan W.S.R Ayurved Prakash Samhita. International Ayurvedic Medical Journal \{online\} 2020 \{cited December, 2020\} Available from: http://www.iamj.in/posts/images/upload/5282 5286.pdf 